\title{
What is the Influence of Maternal Weight Gain in Different Gestational Clinical Conditions on the Prole Weight in Pre-School Age?
}

Márcia Dornelles Machado Mariot

Hospital de Clínicas de Porto Alegre

Daniela Cortés Kretzer ( $\nabla$ danielakretzer@hotmail.com )

Federal University of Rio Grande do Sul

Patrícia Cemin Becker

Federal University of Rio Grande do Sul

Isadora Musse Nunes

Federal University of Rio Grande do Sul

Marcelo Zubaran Goldani

Hospital de Clínicas de Porto Alegre

Juliana Rombaldi Bernardi

Federal University of Rio Grande do Sul

Clécio Homrich da Silva

Hospital de Clínicas de Porto Alegre

\section{Research Article}

Keywords: Maternal and Child Health, Weight gain during pregnancy, Prenatal care, preschool.

Posted Date: February 4th, 2022

DOI: https://doi.org/10.21203/rs.3.rs-1192293/v1

License: (c) (i) This work is licensed under a Creative Commons Attribution 4.0 International License. Read Full License 


\section{Abstract \\ BACKGROUND}

The aim of the current study was to assess the influence of maternal weight gain in different clinical gestational conditions on the child's weight at pre-school age.

\section{METHODS}

longitudinal observational study of a prospective and controlled multiple cohort of 372 mother-child pairs from 2011 to 2016 in three hospitals in Porto Alegre (Brazil). Socio-demographic, prenatal and perinatal data were analyzed. Gestational weight gain (GWG) was categorized as "insufficient", "adequate" and "excessive". The Generalized Estimation Equations (GEE) model was used to assess changes in the Z score of the child's body mass index from birth to preschool age according to the GWG and gestational group.

\section{RESULTS}

A triple interaction effect was observed involving the gestational group, weight gain and time $(p=0.020)$ through an adjusted model. Maternal weight gain above the recommended is associated with a significant increase in the child's Z-BMI score over time, except for children from pregnant smokers. Children from diabetic (DM), hypertensive mothers, and the control group who had a weight gain above that recommended during pregnancy changed their nutritional status from eutrophic to overweight, becoming obese in the DM and hypertension groups and overweight in control.

\section{CONCLUSIONS}

Monitoring of the GWG, especially in the presence of hypertensive diseases and DM, should be effective to prevent children from developing overweight or obesity in preschool age with an important impact on health conditions in the future.

\section{Background}

Childhood obesity is currently considered an important public health problem, as it is increasingly common in preschoolers and schoolchildren. In 2016, 340 million children and adolescents between 5 and 19 years old were overweight or obese, and in children under 5 years old, that number was 40 million [1].

The increase in this prevalence is observed at increasingly early ages and its genesis is related to environmental, genetic and behavioral factors. It is believed that pre-conception and gestational factors 
can also affect the epigenome and influence the risk of developing future metabolic problems in the offspring [2].

A high pre-gestational maternal body mass index (BMI), as well as excessive weight gain during pregnancy, have been associated with an increased risk of developing overweight / obesity in childhood [3]. A survey conducted in China with 4,303 preschool children (3-5 years old) showed that pre-gestational $\mathrm{BMI}$ and inadequate gestational weight gain increased the BMI $Z$ score in children and, therefore, the risk of developing overweight and childhood obesity [4]. In Sweden, it was observed that the pre-conception maternal lifestyle has a direct influence on the child's weight gain and development during the first five years of life [5].

On the other hand, the influence of adverse intrauterine environments on the fetus and the development of chronic non-communicable diseases in adult life is already known. These fetal metabolic responses may cause heart disease, systemic arterial hypertension (SAH) and type 2 diabetes mellitus (DM) [6]. Another example is maternal smoking during pregnancy which may cause negative results in the short and long term, such as restriction of intrauterine growth, preterm birth, low birth weight and sudden infant death syndrome, as well as hypertension, DM and obesity in adult life [7].

More recently, studies have shown that controlling gestational weight gain has proven to be an effective method for reducing overweight and obesity in childhood [8,9], and this measure would probably be more effective during the first gestational trimester, when there is a greater relationship between maternal weight gain and the child's future obesity risk [10].

Considering the increasing prevalence of childhood obesity and its implications for adolescence and adulthood, it is important to investigate its causes, its processes and what are the critical moments for its intervention, including during fetal intrauterine life. Therefore, the present study aims to evaluate the influence of maternal weight gain in different clinical gestational conditions on the child's weight at preschool age.

\section{Methods}

This is a longitudinal observational study nested in a prospective and controlled multiple cohort of a twophase project: the first entitled "Impact of Variations in the Perinatal Environment on the Health of the Newborn in the First Six Months of Life" - IVAPSA and the second, entitled "Variations of the Perinatal Environment on the Health of the Newborn in the First Five Years of Life". Both projects were developed and executed by the research group Núcleo de Estudos em Saúde da Criança e do Adolescente at Federal University of Rio Grande do Sul.

This study included mothers and their respective children between 3 and 6 years old (follow-up phase) who participated in the interview carried out at six months of the child's life (first phase). The total sample size in the first phase of the project was 372 children. From this to the second phase, there were no exclusions, because, in the first phase, HIV-positive mothers and twin newborns, with congenital diseases 
at birth, which required hospitalization or with birth weight below 500 grams had already been excluded. The selection criteria and inclusion in the aforementioned groups of clinical gestational conditions, the recruitment of mother-child pairs, the research instruments, the interviews carried out and the initial research procedures are described in detail in the original articles by Bernardi et al. [11] and Werlang et al. [12].

Data collection of the first phase took place between 2011 and 2016 in two moments: (1) in the recruitment within 48 hours after delivery and (2) in the interview at six months of life of the infant. In recruiting, sociodemographic information was collected, through interviews, and obstetric and perinatal information by way of the Pregnant Woman's Handbook and hospital medical records. In the last interview of the first phase of the project, at six months, information was obtained on breastfeeding time and feeding introduction, in addition to the measurement of anthropometric measurements of infant weight and length. Data collection for the second phase was carried out at the Clinical Research Center of Hospital de Clínicas de Porto Alegre (HCPA), between July 2017 and December 2019. Specific questionnaires were applied to assess nutritional aspects, in addition to measurements of weight and height of the child in duplicate by trained researchers. To assess the energy consumption of preschoolers, a 24-hour recall was applied and, subsequently, their values were calculated according to the Brazilian Food Composition Table [13].

The maternal anthropometric measurements obtained, consecutively, from the Maternity Handbook and the hospital medical record, allowed the calculation of the pre- and post-gestational BMI. Gestational Weight Gain (GWG) was calculated by subtracting the weight measured just before delivery and the pregestational weight. This GWG was categorized as "insufficient", "adequate" and "excessive" according to the Institute of Medicine [14].

To calculate the $Z$ - BMI score values for the child's age and sex, Anthro® (for children under five) and Anthro Plus ${ }^{\circledR}$ (for five years or more) software were used. They have as reference the growth curves proposed by the World Health Organization $[15,16]$.

The children's nutritional status used the $Z$ - BMI score values for children under five and five to ten years old, respectively. Through it, the final classification used was: $<Z$ score $-3=$ marked thinness $/$ marked thinness; $\geq Z$ score -3 and $<Z$ score $-2=$ thinness / thinness; $\geq Z-2$ score and $\leq Z+1$ score $=$ normal weight / normal weight; $>Z$ score +1 and $\leq Z$ score +2 = risk of overweight / overweight; $>Z$ score +2 and $\leq Z$ score $+3=$ overweight $/$ obesity; $>Z$ score +3 = obesity / severe obesity [17].

In statistical analysis, quantitative variables were described as average and standard deviation (SD) or median and interquartile range. Categorical variables were described by absolute and relative frequencies. To compare averages among groups, Analysis of Variance (ANOVA) was used, complemented by the Tukey test. In case of asymmetry, the Kruskal-Wallis test was used, complemented by the Dunn test. To compare proportions, Pearson's chi-square test was used in conjunction with the analysis of adjusted residuals. When comparing the change in the BMI Z score over time, according to maternal weight gain and the groups, the Generalized Estimation Equations (GEE) model was used, 
complemented by the Least Significant Difference (LSD) test, which evaluated the isolated and collective effects of interaction, time and weight gain. The interaction between intrauterine group, GWG and child weight gain (through BMI Z Score) was adjusted for maternal age and education, marital status, family income, pregnancy planning, number of children, pre-gestational BMI, consultations, prenatal care and type of birth. The level of significance adopted was $5 \%(p<0.05)$ and the analyses were performed using the SPSS program (Statistical Package for the Social Sciences) version 21.0.

The IVAPSA study was approved by the Ethics Committees of Hospital de Clínicas de Porto Alegre (110097) and Grupo Hospitalar Conceição (11-027) to carry out the first phase of the study and, subsequently, approved by the Ethics Committee of Hospital de Clínicas de Porto Alegre (17-0107) for the second phase. Both are in accordance with resolution No. 466/2012 of the National Health Council, which regulates the guidelines and rules for research with human beings in Brazil.

When recruiting the first phase of the project, the puerperal women received explanations regarding the objectives of the study and its realization, as well as the possibility of abandoning it without any damage to their care. After signing the Free and Informed Consent Form, the mother-child pair was selected for the research.

\section{Results}

The first phase of the project comprised 371 mother-child pairs, distributed across the five different groups of clinical gestational conditions. Maternal sociodemographic characteristics and the pre and perinatal information distributed in these five groups are shown in Table 1. The following variables showed a significant difference among intrauterine groups: maternal age $(p<0.001)$, child's age $(p=$ 0.012), maternal education ( $p=0.002)$, family income $(p<0.001)$, birth weight $(p<0.001)$, length at birth $(p<0.001)$, number of prenatal consultations $(p<0.001)$, pre-pregnancy BMI $(p<0.001)$, number of previous children $(p=0.003)$, maternal weight gain $(p=0.021)$, pregnancy planning $(p<0.001)$, living with a partner $(p=0.007)$ and type of birth $(p<0.001)$. 
Table 1

Characterization of the sample in the different intrauterine groups according to maternal sociodemographic characteristics, prenatal and neonatal data.

\begin{tabular}{|c|c|c|c|c|c|c|}
\hline Variables & DM & Hypertension & Tobacco & IUGR & Control & $\mathbf{P}$ \\
\hline Mother age (years) & $\begin{array}{l}28.2 \pm \\
5.8 \mathrm{~b}\end{array}$ & $28.7 \pm 6.9 b$ & $\begin{array}{l}24.6 \pm \\
5.7 \mathrm{a}\end{array}$ & $\begin{array}{l}23.9 \pm \\
6.0 \mathrm{a}\end{array}$ & $\begin{array}{l}25.7 \pm \\
6.9 \mathrm{ab}\end{array}$ & 0.001 \\
\hline Child's age (years) & $\begin{array}{l}4.00 \pm \\
0.92 \mathrm{a}\end{array}$ & $\begin{array}{l}4.50 \pm \\
0.76 \mathrm{ab}\end{array}$ & $\begin{array}{l}4.90 \pm \\
0.55 \mathrm{~b}\end{array}$ & $\begin{array}{l}4.33 \pm \\
1.05 \mathrm{ab}\end{array}$ & $\begin{array}{l}4.57 \pm \\
0.77 \mathrm{ab}\end{array}$ & 0.012 \\
\hline $\begin{array}{l}\text { Mother's schooling } \\
\text { (years) }\end{array}$ & $\begin{array}{l}10.0 \pm \\
3.16 \mathrm{~b}\end{array}$ & $\begin{array}{l}9.12 \pm \\
2.93 \mathrm{ab}\end{array}$ & $\begin{array}{l}8.37 \pm \\
2.63 \mathrm{a}\end{array}$ & $\begin{array}{l}9.74 \pm \\
2.21 \mathrm{ab}\end{array}$ & $\begin{array}{l}9.49 \pm \\
2.53 \mathrm{~b}\end{array}$ & 0.002 \\
\hline $\begin{array}{l}\text { Family income } \\
\text { (reais) }\end{array}$ & $\begin{array}{l}1500 \\
(1100- \\
2900) b\end{array}$ & $\begin{array}{l}1500(950- \\
2250) \mathrm{ab}\end{array}$ & $\begin{array}{l}1240 \\
(800- \\
1900) a\end{array}$ & $\begin{array}{l}1600 \\
(1085- \\
3000) a b\end{array}$ & $\begin{array}{l}2000 \\
(1210- \\
3000) b\end{array}$ & $<0.001$ \\
\hline $\begin{array}{l}\text { Had a partner (n, } \\
\%)\end{array}$ & $52(83.9)$ & $21(80.8)$ & $\underset{* *}{57}(65.5)$ & 30 (83.3) & $\begin{array}{l}136(84.5) \\
\star\end{array}$ & 0.007 \\
\hline $\begin{array}{l}\text { White ethnicity (n, } \\
\%)\end{array}$ & $40(65.6)$ & $18(69.2)$ & $51(58.6)$ & $16(44.4)$ & $98(60.9)$ & 0.243 \\
\hline $\begin{array}{l}\text { Number of people } \\
\text { in the house }\end{array}$ & $4(3-5)$ & $4.5(3-5)$ & $4(4-6)$ & $4(3-5)$ & $4(3-6)$ & 0.213 \\
\hline $\begin{array}{l}\text { Number of PN } \\
\text { consultations }\end{array}$ & $\begin{array}{l}9.81 \pm \\
3.50 \mathrm{c}\end{array}$ & $\begin{array}{l}9.19 \pm \\
2.70 \mathrm{bc}\end{array}$ & $\begin{array}{l}6.40 \pm \\
2.84 \mathrm{a}\end{array}$ & $\begin{array}{l}7.61 \pm \\
3.10 \mathrm{ab}\end{array}$ & $\begin{array}{l}8.08 \pm \\
2.92 \mathrm{ab}\end{array}$ & $<0.001$ \\
\hline $\begin{array}{l}\text { Planned } \\
\text { pregnancy }(n, \%)\end{array}$ & $29(46.8)$ * & $10(38.5)$ & $\underset{\star \star}{14}(16.1)$ & $14(38.9)$ & $63(39.1)$ & 0.001 \\
\hline $\begin{array}{l}\text { Number of } \\
\text { previous children }\end{array}$ & $\begin{array}{l}2(0- \\
\text { 3) } \mathrm{ab}\end{array}$ & $2(0-3) a b$ & $2(0-3) b$ & $0(0-2) a$ & $1(0-2) a$ & 0.003 \\
\hline $\begin{array}{l}\text { Combined GA } \\
\text { (weeks) }\end{array}$ & $\begin{array}{l}39.0 \pm \\
1.19\end{array}$ & $38.6 \pm 1.10$ & $\begin{array}{l}39.2 \pm \\
1.33\end{array}$ & $38.9 \pm 1.31$ & $\begin{array}{l}39.3 \pm \\
1.19\end{array}$ & 0.051 \\
\hline Pre BMI $\left(\mathrm{Kg} / \mathrm{m}^{2}\right)$ & $\begin{array}{l}28.6 \pm \\
6.03 \mathrm{c}\end{array}$ & $\begin{array}{l}27.1 \pm \\
5.74 \mathrm{bc}\end{array}$ & $\begin{array}{l}24.8 \pm \\
4.79 \mathrm{ab}\end{array}$ & $\begin{array}{l}22.6 \pm \\
4.16 \mathrm{a}\end{array}$ & $\begin{array}{l}25.3 \pm \\
4.74 \mathrm{ab}\end{array}$ & $<0.001$ \\
\hline $\begin{array}{l}\text { Maternal weight } \\
\text { gain }(\mathrm{g})\end{array}$ & $\begin{array}{l}12.6(8- \\
17.3) \mathrm{ab}\end{array}$ & $\begin{array}{l}16.5(13- \\
19.7) \mathrm{b}\end{array}$ & $\begin{array}{l}14.0(9.5- \\
18) \mathrm{ab}\end{array}$ & $\begin{array}{l}11.4(7.7- \\
15.4) \mathrm{a}\end{array}$ & $\begin{array}{l}13.31(10 \\
-18.3) a b\end{array}$ & 0.021 \\
\hline $\begin{array}{l}\text { Maternal weight } \\
\text { gain }\end{array}$ & & & & & & 0.026 \\
\hline Insufficient & $15(26.3)$ & $3(13.0)$ & $21(26.9)$ & $13(39.4)$ & $40(27.8)$ & \\
\hline Adequate & $14(24.6)$ & $3(13.0)$ & $17(21.8)$ & $13(39.4)$ & $42(29.2)$ & \\
\hline Excessive & $28(49.1)$ & $17(73.9)$ * & $40(51.3)$ & $7(21.2)$ ** & $62(43.1)$ & \\
\hline
\end{tabular}

a, b, c Equal letters do not differ by the Tukey or Dunn test at $5 \%$ significance * Positive association by the residual test adjusted to $5 \%$ significance; ${ }^{\star \star}$ negative association by the residual test adjusted to $5 \%$ significance. 


\begin{tabular}{|c|c|c|c|c|c|c|}
\hline Variables & DM & Hypertension & Tobacco & IUGR & Control & $\mathbf{P}$ \\
\hline Vaginal Birth (n\%) & ${ }_{* \star}^{34}(54.8)$ & $9(34.6)$ ** & $65(74.7)$ & $24(66.7)$ & $114(70.8)$ & 0.001 \\
\hline Birth weight (g) & $\begin{array}{l}3451 \pm \\
453 c\end{array}$ & $\begin{array}{l}3265 \pm \\
523 \mathrm{bc}\end{array}$ & $\begin{array}{l}3114 \pm \\
403 \mathrm{~b}\end{array}$ & $\begin{array}{l}2528 \pm \\
173 a\end{array}$ & $\begin{array}{l}3385 \pm \\
451 \mathrm{c}\end{array}$ & $<0.001$ \\
\hline $\begin{array}{l}\text { Length at birth } \\
\text { (cm) }\end{array}$ & $\begin{array}{l}49.0 \pm \\
1.95 \mathrm{c}\end{array}$ & $\begin{array}{l}48.4 \pm \\
1.88 \mathrm{bc}\end{array}$ & $\begin{array}{l}48.0 \pm \\
2.25 \mathrm{~b}\end{array}$ & $\begin{array}{l}46.1 \pm \\
1.61 \mathrm{a}\end{array}$ & $\begin{array}{l}49.3 \pm \\
2.03 \mathrm{c}\end{array}$ & $<0.001$ \\
\hline $\begin{array}{l}\text { Female gender }(\mathrm{n}, \\
\%)\end{array}$ & $33(53.2)$ & $14(53.8)$ & $43(49.4)$ & $21(58.3)$ & 89 (55.3) & 0.892 \\
\hline $\begin{array}{l}\text { Breastfeeding } \\
\text { Time (days) }\end{array}$ & $\begin{array}{l}180(135- \\
180)\end{array}$ & $\begin{array}{l}180(131- \\
180)\end{array}$ & $\begin{array}{l}180(62- \\
180)\end{array}$ & $\begin{array}{l}180(129- \\
180)\end{array}$ & $\begin{array}{l}180(150- \\
180)\end{array}$ & 0.905 \\
\hline $\begin{array}{l}\text { Total caloric } \\
\text { consumption } \\
\text { (Kcal) }\end{array}$ & $\begin{array}{l}2200 \pm \\
793\end{array}$ & $2098 \pm 418$ & $\begin{array}{l}2227 \pm \\
695\end{array}$ & $\begin{array}{l}2398 \pm \\
1014\end{array}$ & $\begin{array}{l}2223 \pm \\
817\end{array}$ & 0.923 \\
\hline $\begin{array}{l}\text { Introduction of } \\
\text { solid foods } \\
\text { (months) }\end{array}$ & $5(4-6)$ & $6(4-6)$ & $4(3-6)$ & $6(5-6)$ & $6(4-6)$ & 0.614 \\
\hline $\begin{array}{l}\text { a, b, c Equal letters } \\
\text { the residual test ad } \\
5 \% \text { significance. }\end{array}$ & $\begin{array}{l}\text { lot differ } \\
\text { ed to } 5 \%\end{array}$ & $\begin{array}{l}\text { Tukey or } \\
\text { cance; } * \star\end{array}$ & $\begin{array}{l}\text { test at } \\
\text { ive assc }\end{array}$ & $\begin{array}{l}\text { gnificanc } \\
\text { on by the }\end{array}$ & $\begin{array}{l}\text { sitive ass } \\
\text { lal test ad }\end{array}$ & $\begin{array}{l}\text { ation by } \\
\text { ted to }\end{array}$ \\
\hline
\end{tabular}

In the DM and hypertension groups, there was higher average of pre-gestational BMI (28.6 \pm 6.03 and $27.1 \pm 5.74$, respectively) and higher average of the number of prenatal consultations $(9.81 \pm 3.50$ and $9.19 \pm 2.70$, respectively). Most women in the hypertension group had maternal weight gain above the recommended (73.9\%), while the weight gain of those belonging to the intrauterine growth restriction (IUGR) was predominantly adequate $(39.4 \%)$ or below $(39.4 \%)$ the recommended. The lowest rate of vaginal birth was found in the hypertension group (34.6\%). As for the child's characteristics, the lowest average $( \pm S D)$ of birth weight was found in the IUGR group (2528 $\mathrm{g} \pm 173)$, as well as that of length at birth $(46.1 \mathrm{~cm} \pm 1.61)$. The other variables presented, such as duration of breastfeeding and total caloric consumption, did not have a statistically significant difference across groups (Table 1).

[Insert Table 1]

The crude and adjusted analysis of the interaction between maternal weight gain and the variation of the $Z$ score - BMI of children between 6 months of age and preschool age are found, respectively, in Tables 2 and 3. The effect of triple interaction involving the group of clinical gestational conditions, the maternal weight gain during pregnancy and the study time is shown in Table 2. There was interaction of maternal weight gain and elevation of the child's Z score - BMI in the mothers of the DM group who had adequate GWG $(p=0.001)$ or excessive GWG $(p=0.010)$, in those of the hypertension group with adequate GWG ( $=0.002)$ or excessive GWG ( $p=0.004)$, in those of the IUGR group with insufficient GWG $(p=0.035)$ or excessive GWG ( $p=0.035)$ and in those of the control group for excessive GWG $(p<0.001)$ (Table 2$)$. 
Table 2

Crude analysis of the interaction between the group and gestational weight gain in the child's weight gain using the Z/BMl score

\begin{tabular}{|c|c|c|c|c|c|c|}
\hline \multicolumn{2}{|c|}{$\begin{array}{l}\text { Groups Gestational } \\
\text { Weight Gain }\end{array}$} & \multirow{2}{*}{$\begin{array}{l}\text { Average } \\
(6 \mathrm{~m}) \\
0.44\end{array}$} & \multirow{2}{*}{$\begin{array}{l}\text { Error } \\
\text { Standard } \\
0.43\end{array}$} & \multirow{2}{*}{$\begin{array}{l}\text { Average } \\
\text { (3-6 years) } \\
0.02\end{array}$} & \multirow{2}{*}{$\begin{array}{l}\text { Error } \\
\text { standard } \\
0.38\end{array}$} & \multirow{2}{*}{$\begin{array}{l}\mathbf{P} \\
0.462\end{array}$} \\
\hline DM & Insufficient & & & & & \\
\hline & Adequate & 0.74 & 0.34 & 2.69 & 0.39 & 0.001 \\
\hline & Excessive & 0.53 & 0.22 & 1.67 & 0.53 & 0.010 \\
\hline \multirow[t]{3}{*}{ HYPERTENSION } & Insufficient & - & - & -0.36 & 0.00 & - \\
\hline & Adequate & -0.38 & 0.29 & 0.55 & 0.00 & 0.002 \\
\hline & Excessive & 0.09 & 0.24 & 2.92 & 0.98 & 0.004 \\
\hline \multirow[t]{3}{*}{ TOBACCO } & Insufficient & -0.25 & 0.24 & 0.29 & 0.61 & 0.341 \\
\hline & Adequate & 0.22 & 0.28 & 0.75 & 0.52 & 0.332 \\
\hline & Excessive & 0.30 & 0.34 & 0.77 & 0.61 & 0.423 \\
\hline \multirow[t]{3}{*}{ IUGR } & Insufficient & 0.21 & 0.30 & -0.38 & 0.09 & 0.035 \\
\hline & Adequate & 0.16 & 0.40 & 1.08 & 0.33 & 0.081 \\
\hline & Excessive & -1.30 & 0.39 & -0.41 & 0.37 & 0.035 \\
\hline \multirow[t]{3}{*}{ CONTROL } & Insufficient & 0.12 & 0.23 & 0.47 & 0.21 & 0.276 \\
\hline & Adequate & 0.20 & 0.22 & 0.38 & 0.28 & 0.592 \\
\hline & Excessive & 0.27 & 0.15 & 1.15 & 0.20 & $<0.001$ \\
\hline \multicolumn{7}{|c|}{ Triple interaction effect (group $x$ GP $\times$ time); $p=0.048}$. \\
\hline
\end{tabular}

[Insert Table 2]

In the adjusted model, the effect of triple interaction between the intrauterine group, weight gain and study time remained statistically significant $(p=0.020)$. In the DM group, women with adequate $(p=$ $0.001)$ or excessive $(p=0.008)$ weight gain had children who had a significant increase in the $Z$ - BMI score. On average, adequate and excessive weight gain resulted in changes in the classification of the nutritional status from eutrophic to overweight (for children under five) and obesity (for children over five) and from eutrophic to risk of overweight (for children under five) and overweight (for children over five), respectively. The children of women in the hypertension group who had weight gain above the recommended had children with significant increase in the Z score - BMI ( $p=0.004)$, indicating a change from eutrophic to overweight (children under five years old) or obesity (children older than 5 years). Women belonging to the control group with excessive gestational weight gain had, on average, children 
with increased Z score - BMI ( $\mathrm{p}<0.001)$ over time, starting to be classified as eutrophic for risk of overweight (children under five years old) or overweight (children older than 5 years) at preschool age (Table 3).

Table 3 - Analysis adjusted to the interaction between group and gestational weight gain in the child's weight gain using the Z Score - BMI.

\begin{tabular}{|c|c|c|c|c|c|c|}
\hline Groups & $\begin{array}{l}\text { Gestational } \\
\text { Weight Gain }\end{array}$ & $\begin{array}{l}\text { Average } \\
(6 \mathrm{~m})\end{array}$ & $\begin{array}{l}\text { Error } \\
\text { standard }\end{array}$ & $\begin{array}{l}\text { Average } \\
\text { (3-6 years) }\end{array}$ & $\begin{array}{l}\text { Error } \\
\text { standard }\end{array}$ & $\mathbf{P}$ \\
\hline \multirow[t]{3}{*}{ DM } & Insufficient & 0.32 & 2.13 & 0.04 & 2.18 & 0.621 \\
\hline & Adequate & 0.61 & 2.18 & 2.71 & 2.17 & 0.001 \\
\hline & Excessive & 0.45 & 2.14 & 1.62 & 2.24 & 0.008 \\
\hline \multirow[t]{3}{*}{ HYPERTENSION } & Insufficient & - & - & -0.28 & 2.30 & - \\
\hline & Adequate & -0.42 & 2.18 & 0.21 & 2.00 & 0.021 \\
\hline & Excessive & -0.00 & 2.16 & 2.75 & 2.33 & 0.004 \\
\hline \multirow[t]{3}{*}{ TOBACCO } & Insufficient & -0.13 & 2.22 & 0.40 & 2.23 & 0.321 \\
\hline & Adequate & 0.49 & 2.27 & 0.87 & 2.30 & 0.521 \\
\hline & Excessive & 0.37 & 2.29 & 0.86 & 2.45 & 0.395 \\
\hline \multirow[t]{3}{*}{ IUGR } & Insufficient & 0.48 & 2.28 & -0.15 & 2.26 & 0.032 \\
\hline & Adequate & 0.40 & 2.28 & 1.33 & 2.28 & 0.081 \\
\hline & Excessive & -1.16 & 2.25 & -0.25 & 2.22 & 0.026 \\
\hline \multirow[t]{3}{*}{ CONTROL } & Insufficient & 0.20 & 2.22 & 0.65 & 2.20 & 0.162 \\
\hline & Adequate & 0.37 & 2.21 & 0.56 & 2.28 & 0.573 \\
\hline & Excessive & 0.32 & 2.19 & 1.17 & 2.19 & $<0.001$ \\
\hline
\end{tabular}

adjusted for maternal age, maternal education, family income, type of birth, number of children, pre pregnancy BMI, prenatal consultations, pregnancy planning and marital status (triple interaction effect (group x GP vs. time); $p=0.020$ ).

[Insert Table 3]

Figure 1 represent the variation in the child's Z - BMI score between 6 months of age and preschool age, categorized by adequate and excessive gestational weight gain, respectively. In general, maternal weight 
gain above the recommended is associated with an increase in the child Z - BMI score over time, except among the children of pregnant smokers (Figure 1).

[Insert Figure 1]

It is observed that there was a transition in the classification of children's nutritional status that ranged from eutrophy to the risk of overweight, overweight and even obesity according to their age group and the GWG by group of clinical gestational conditions.

\section{Discussion}

The results of the present study demonstrated that excessive maternal weight gain is associated with a significant increase in the BMI Z score for age in preschool children, except for children from the pregnant smokers group. The children of mothers in the DM, hypertension and control groups, who had weight gain above the recommended during pregnancy, modified their classification of nutritional status at preschool age. Those from the DM and hypertension groups became obese and those from the control group were overweight.

Excessive weight gain during pregnancy had already been associated with higher Z- BMI score and also with the prevalence of overweight throughout childhood [18]. Besides, pregnant women who are overweight during pregnancy increases the risk of their offspring developing overweight and obesity, in addition to other metabolic complications, in the future, including transgenerationally [9].

From the obstetric point of view, the number of prenatal consultations for pregnant women was significantly higher in the DM group and lower in the tobacco group when compared to the other groups. Pregnancy planning was lower among mothers in the tobacco group (16\%), who also had greater number of children. The greater number of prenatal consultations among mothers in the DM group is probably justified by the fact that they were referred to the High Risk Prenatal Care, which provides for a greater number of consultations due to the need for frequent monitoring the high gestational risk [19]. Still on prenatal care, a survey conducted in the Northeast of Brazil found that fewer than six consultations by pregnant women are associated with excessive weight gain among low-income preschoolers in Early Childhood Education Centers [20].

As for the type of birth, mothers in the hypertension and DM groups had the highest frequency of cesarean sections, respectively, $45.2 \%$ and $65.4 \%$. According to a study carried out in the interior of Bahia, in the Northeast Region of Brazil, cesarean birth showed an association with excess weight in preschoolers [21]. Therefore, this type of birth may also have contributed in some way to the overweight observed in mothers' school-age children, precisely in these two groups, in addition to other possible metabolic factors involved.

Regarding weight gain during pregnancy, it was higher among pregnant women in the hypertension group and the lowest among those in the IUGR group. The assessment of weight gain categorized as 
insufficient, adequate or excessive showed maternal weight gain above the recommended in all groups, except for mothers with IUGR, who maintained weight gain below the expected or adequate. Previous publications on the topic reported that maternal over-nutrition during pregnancy has repercussions on the child health in the medium and long term, since metabolic changes that occur during fetal development can generate epigenetic changes, which will play an important role in the prevalence of transmitted obesity across generations. The conclusions of these articles reinforced the importance of weight control, both before and during pregnancy, and consumption of healthy foods in this period can reduce the risks of fetal programming of metabolic diseases [22-24].

In this sense, a cohort study evaluated the association between birth weight and gene expression in fetal obesity programming and concluded that the genes regulating glycemic control, appetite balance and inflammatory process were altered in the tissues of children born with high birth weight and that these genes can demonstrate important changes in fetal programming [25]. In this context, gestational weight gain is essential to characterize maternal nutrition. The assessment of total caloric intake in the different intrauterine groups studied was shown to be statistically similar, with previous research of the first phase of the project already published previously [26].

Regarding preschool children born to mothers who smoked, there was no association between their $Z$ score for $\mathrm{BMI}$ at preschool age and maternal weight gain during pregnancy. The children of mothers in the IUGR group had their Z score for BMI altered by maternal weight gain, but without changing their nutritional status. It should be noted, however, that these mothers should not have weight gain below the recommended, as this will possibly have an even greater impact on their children's low birth weight. Thus, the concern about gestational weight gain was relevant in a systematic review with a meta-analysis that included more than 1 million pregnant women. The results showed that gestational weight gain above or below the recommended, when compared with the appropriate gestational weight gain, was associated with a greater risk of adverse effects for the mother-child binomial [27].

The greatest gestational weight gain among mothers in the hypertension group stood out compared to the other groups of clinical gestational conditions. Among them, $74 \%$ had gained weight above the recommended, which showed an association with the nutritional transition in their children's preschool age. Similar findings have also recently been described by Skrypnik et al. [28] confirming the association of maternal hypertension during pregnancy with the risk of developing childhood obesity. Although mothers in the hypertension group had greater number of prenatal consultations, they were not effective in controlling weight gain. This reinforces the need for adjustments in prenatal care, especially at high risk in relation to maternal food consumption.

With regard to mothers in the DM group, they were the ones who had the highest pre-gestational BMI and adequate gestational weight gain when compared to mothers in the other groups. However, almost half of them were classified as having excessive weight gain and had children with the highest birth weight. The Cambridge Baby Growth Study investigated the association between fetal allele score and birth weight with maternal glucose concentrations. The results showed that in non-diabetic mothers the 
regulation is related only to glucose-independent mechanisms, while in diabetic glucose-dependent mechanisms were involved, modifying the results of weight gain [29].

In a peculiar way, even pregnant women with weight gain considered adequate had their children with a mean Z score for high BMI with a diagnosis of overweight (for children under five years old) and obesity (for children over five years old). These findings, according to some researchers, indicate that the association between maternal GWG and the BMI of the offspring may have several other mechanisms involved, mainly genetic, those related to lifestyle and fetal programming in the intrauterine environment [8]. Complementarily, a cohort study conducted in Rio de Janeiro with puerperal women and their full-term newborns found that excess GWG, maternal comorbidities and perinatal factors caused changes in the newborn's body composition [30].

One of the probable hypotheses to explain this relationship between adequate gestational weight gain and overweight in preschool age is that weight gain is triggered by effectors from adipose tissue (such as adipokines and inflammatory cytokines). These can be modified in the presence of maternal DM, which also releases countless other effectors activated by the metabolic lack of control present in the disease, such as, for example, hyperglycemia accompanied or not by insulinemic variations. In summary, in women without DM during pregnancy, the weight evolution of offspring is strictly related to gestational weight gain, while in women with the disease this association disappears, as there is a possible modulation of the various competing metabolic factors that induce different forms of fetal programming. This assumption is in line with a study carried out by a Danish National Birth Cohort, which aimed to investigate the association of fasting plasma glucose concentrations during pregnancy with the growth of offspring and the risk of overweight / obesity up to 7 years of age and demonstrated that the highest concentrations of maternal plasma glucose during pregnancy showed a statistically significant association with overweight / obesity of the offspring at the age of 7 years [31].

Another complementary hypothesis is related to the prenatal care received by diabetic pregnant women. Depending on the obstetric clinical condition, treatment is dietary or pharmacological. When metformin is used, for example, there is metabolic regulation through pharmacological effectors. Children of mothers who used this medication during pregnancy had greater weight and head circumference at 18 months of age [32] and greater risk of overweight / obesity at the age of four [33, 34].

Among the positive aspects of the study, we highlight the investigation of the weight gain of pregnant women influence, comparatively, in different clinical conditions on the weight of the preschool child, which characterizes an unprecedented research to date. Also the anthropometric measurements taken, in person, of the newborn, passing through the infant, until preschool age, as well as the use of several covariates in the analyses considered as confounding or measuring factors in the investigated outcome. Instead, the sample loss from the first to the second phase of the research, inherent in a longitudinal study, is considered one of the limitations of the study, although it is understandable for a diverse sample distributed in a municipality with a large territorial area, high urban mobility and frequent changes in telephone numbers and even home address. 
Excessive maternal weight gain in pregnant women from the different clinical conditions studied (DM, hypertension, IUGR and control) showed a statistically significant association with the $Z$ score for BMI in children of preschool age, except for children of pregnant smokers. Children of pregnant women in the DM, hypertension and control groups had, in the age group of three to six years, a change in their classification of nutritional status from eutrophic to overweight. These results allow us to conclude that maternal weight gain in different clinical gestational conditions influenced the weight of preschool children.

\section{Conclusion}

The hypothesis that metabolic factors resulting from hypertension or DM during pregnancy, in addition to intrauterine fetal programming, exercise different modulations in the evolution of the child's weight, which increases the $\mathrm{Z}$ score for $\mathrm{BMI}$ according to age. Thus, the study reinforces the importance of adequate maternal weight gain during pregnancy, as well as effective prenatal care, especially in the presence of diseases such as hypertension and Diabetes Mellitus, as a way to prevent the development of overweight/obesity in childhood.

\section{Abbreviations}

BMI: body mass index; SAH: systemic arterial hypertension; DM: diabetes mellitus; IPVEH: Impact of Variations in the Perinatal Environment on the Health of the Newborn in the First Six Months of Life; HCPA: Hospital de Clínicas de Porto Alegre; GWG: Gestational Weight Gain; GEE: Generalized Estimation Equations; LSD: Least Significant Difference; SPSS: Statistical Package for the Social Sciences; IUGR: Intrauterine Growth Restriction.

\section{Declarations}

\section{Ethics approval and consent to participate}

Ethical approval to conduct this study has been granted by the Hospital de Clínicas de Porto Alegre (HCPA) and the Grupo Hospitalar Conceição (GHC) - Hospital Nossa Senhora da Conceição (HNSC) and Hospital Fêmina (HF) - under numbers 11-0097 and 11-027, respectively. Adult participants and the parents/guardians of minors have signed an informed consent form in duplicate, keeping one copy of it.

The authors declare that all methods were carried out in accordance with relevant guidelines and regulations.

\section{Consent for publication}

Not applicable.

\section{Availability of data and materials}


The datasets generated and/or analysed during the current study are not publicly available due this is a longitudinal study with probability of follow-up and addition of data to the database, but are available from the corresponding author on reasonable request.

\section{Competing interests}

The authors declare that they have no competing interests.

\section{Funding}

The first part of the study, conducted from 2011 to 2016, was funded by Coordenação de Aperfeiçoamento de Pessoal de Nível Superior - Brasil (CAPES) - Finance Code 001 and Conselho Nacional de Desenvolvimento Científico e Tecnológico - CNPq.

The second part, conducted from 2017 to 2019, was funded by the Research and Events Incentive Fund Hospital de Clínicas de Porto Alegre under grant number 2016-0447. Both funding was used only in these phases of the research: purchase of material, in the collection, processing and analysis of the data.

\section{Author contributions}

MDM conceived the study. All authors contributed to the study design and implementation methods. MDM, DCK, PCB and IMN participated in the recruitment of individuals, application of protocols and data collection. All authors contributed to the refinement of the study and approved the final manuscript.

All authors have read and approved the manuscript.

\section{Acknowledgements}

We would like to thank the women and children who participated in the study. We would also like to thank the financial support from the Brazilian National Council for Scientific and Technological Development (CNPq) and the Coordination for the Improvement of Higher Education Personnel (CAPES).

\section{References}

1. World Health Organization. Noncommunicable diseases country profiles 2018. Geneva: WHO; 2018.

2. Felix JF, Cecil CAM. Population DNA methylation studies in the Developmental Origins of Health and Disease (DOHaD) framework. J Dev Orig Health Dis. 2019;10(3):306-13. https://doi.org/10.1017/S2040174418000442

3. Josey MJ, McCullough LE, Hoyo C, Williams-DeVane C. Overall gestational weight gain mediates the relationship between maternal and child obesity. BMC Public Health. 2019;19(1):1062. https://doi.org/10.1186/s12889-019-7349-1

4. Shao T, Tao H, Ni L, Sun Y, Yan S, Gu C, et al. [Maternal pre-pregnancy body mass index and gestational weight gain with preschool children's overweight and obesity]. Zhonghua Yu Fang Yi Xue 
Za Zhi. 2016;50(2):123-8. https://doi.org/10.3760/cma.j.issn.0253-9624.2016.02.005

5. Claesson IM, Josefsson A, Olhager E, Oldin C, Sydsjö G. Effects of a gestational weight gain restriction program for obese women: Sibling pairs' weight development during the first five years of life. Sex Reprod Healthc. 2018;17:65-74. https://doi.org/10.1016/j.srhc.2018.07.003

6. Godfrey KM, Lillycrop KA, Burdge GC, Gluckman PD, Hanson MA. Non-imprinted epigenetics in fetal and postnatal development and growth. Nestle Nutr Inst Workshop Ser. 2013;71:57-63. https://doi.org/10.1159/000342552

7. Banderali G, Martelli A, Landi M, Moretti F, Betti F, Radaelli G, et al. Short and long term health effects of parental tobacco smoking during pregnancy and lactation: a descriptive review. J Transl Med. 2015;13:327. https://doi.org/10.1186/s12967-015-0690-y

8. van Rossem L, Wijga AH, Gehring U, Koppelman GH, Smit HA. Maternal Gestational and Postdelivery Weight Gain and Child Weight. Pediatrics. 2015;136(5):e1294-301. https://doi.org/10.1542/peds.2015-0874

9. Voerman E, Santos S, Patro Golab B, Amiano P, Ballester F, Barros H, et al. Maternal body mass index, gestational weight gain, and the risk of overweight and obesity across childhood: An individual participant data meta-analysis. PLoS Med. 2019;16(2):e1002744.

https://doi.org/10.1371/journal.pmed.1002744

10. Lu W, Zhang X, Wu J, Mao X, Shen X, Chen Q, et al. Association between trimester-specific gestational weight gain and childhood obesity at 5 years of age: results from Shanghai obesity cohort. BMC Pediatr. 2019;19(1):139. https://doi.org/10.1186/s12887-019-1517-4

11. Bernardi JR, Ferreira CF, Nunes M, da Silva CH, Bosa VL, Silveira PP, et al. Impact of Perinatal Different Intrauterine Environments on Child Growth and Development in the First Six Months of Life-IVAPSA Birth Cohort: rationale, design, and methods. BMC Pregnancy Childbirth. 2012;12:25. https://doi.org/10.1186/1471-2393-12-25

12. Werlang ICR, Bernardi JR, Nunes M, Marcelino TB, Bosa VL, Michalowski MB, et al. Impact of Perinatal Different Intrauterine Environments on Child Growth and Development: Planning and Baseline Data for a Cohort Study. JMIR Res Protoc. 2019;8(11):e12970. https://doi.org/10.2196/12970

13. Núcleo de Estudos e Pesquisas em Alimentação (NEPA). Tabela Brasileira de Composição de Alimentos - TACO [Brazilian Table of Food Composition] 4th ed. Campinas: State University of Campinas (UNICAMP); 2011. p. 161.

14. Rasmussen, KM, Yaktine, AL, Institute of Medicine (US) and National Research Council (US) Committee to Reexamine IOM Pregnancy Weight Guidelines. Weight Gain During Pregnancy: Reexamining the Guidelines. 2009. Washington (DC): National Academies Press (US); 2009.

15. World Health Organization. WHO child growth standards: length / height-for-age, weight-for-age, weight-for-length, weight-for-height and body mass index-for-age. Geneva: WHO; 2006.

16. de Onis M, Onyango AW, Borghi E, Siyam A, Nishida C, Siekmann J. Development of a WHO growth reference for school-aged children and adolescents. Bull World Health Organ. 2007;85(9):660-7. 
https://doi.org/10.2471/blt.07.043497

17. Brasil. Ministério da Saúde. Orientações para a coleta e análise de dados antropométricos em serviços de saúde: Norma Técnica do Sistema de Vigilância Alimentar e Nutricional - SISVAN [Guidelines for the collection and analysis of anthropometric health data: Technical Norm of the Food and Nutritional Surveillance System - SISVAN]. Brasília: Ministério da Saúde; 2011. p. 76.

18. Jin WY, Lv Y, Bao Y, Tang L, Zhu ZW, Shao J, et al. Independent and Combined Effects of Maternal Prepregnancy Body Mass Index and Gestational Weight Gain on Offspring Growth at 0-3 Years of Age. Biomed Res Int. 2016;2016:4720785. https://doi.org/10.1155/2016/4720785

19. Brasil. Ministério da Saúde. Secretaria de Atenção à Saúde. Departamento de Ações Programáticas Estratégicas. Gestação de alto risco: manual técnico [High-risk pregnancy: technical manual]. 5th ed. Brasília: Editora do Ministério da Saúde; 2012. p. 302.

20. Almeida NB, Menezes RCE, Sobral KDS, Gomes JF, Longo-Silva G, Silveira JACD. Pre- and perinatal factors associated with weight gain among preschool children enrolled at day care centers. Rev Paul Pediatr. 2020;38:e2019060. https://doi.org/10.1590/1984-0462/2020/38/2019060

21. Gomes AT, Novaes TG, Silveira KC, Souza CL, Lamounier JA, Netto MP, et al. Excess weight and factors associated in preschool of southwest of Bahia. Rev Bras Saúde Mater Infant. 2017;17(2):9. https://doi.org/10.1590/1806-93042017000200009

22. Montalvo-Martínez L, Maldonado-Ruiz R, Cárdenas-Tueme M, Reséndez-Pérez D, Camacho A. Maternal Overnutrition Programs Central Inflammation and Addiction-Like Behavior in Offspring. Biomed Res Int. 2018;2018:8061389. https://doi.org/10.1155/2018/8061389

23. Şanlı E, Kabaran S. Maternal Obesity, Maternal Overnutrition and Fetal Programming: Effects of Epigenetic Mechanisms on the Development of Metabolic Disorders. Curr Genomics. 2019;20(6):41927. https://doi.org/10.2174/1389202920666191030092225

24. Algaba-Chueca F, Maymó-Masip E, Ejarque M, Ballesteros M, Llauradó G, López C, et al. Gestational diabetes impacts fetal precursor cell responses with potential consequences for offspring. Stem Cells Transl Med. 2020;9(3):351-63. https://doi.org/10.1002/sctm.19-0242

25. Reynolds LJ, Pollack RI, Charnigo RJ, Rashid CS, Stromberg AJ, Shen S, et al. Increased birth weight is associated with altered gene expression in neonatal foreskin. J Dev Orig Health Dis. 2017;8(5):57583. https://doi.org/10.1017/S2040174417000290

26. Becker PC, Mariot MDM, Kretzer DC, Bosa VL, Goldani MZ, da Silva CH, et al. Can the pregnant woman's food intake be influenced by her clinical condition during pregnancy? Rev Bras Saúde Mater Infant. 2020;20(2):10. https://doi.org/10.1590/1806-93042020000200011

27. Goldstein RF, Abell SK, Ranasinha S, Misso M, Boyle JA, Black MH, et al. Association of Gestational Weight Gain With Maternal and Infant Outcomes: A Systematic Review and Meta-analysis. JAMA. 2017;317(21):2207-25. https://doi.org/10.1001/jama.2017.3635

28. Skrypnik D, Bogdański P, Zawiejska A, Wender-Ożegowska E. Role of gestational weight gain, gestational diabetes, breastfeeding, and hypertension in mother-to-child obesity transmission. Pol Arch Intern Med. 2019;129(4):267-75. https://doi.org/10.20452/pamw.4426 
29. Petry CJ, Ong KK, Hughes IA, Acerini CL, Dunger DB. The influence of maternal pregnancy glucose concentrations on associations between a fetal imprinted gene allele score and offspring size at birth. BMC Res Notes. 2018;11(1):821. https://doi.org/10.1186/s13104-018-3933-1

30. Nehab SRG. A influência de fatores gestacionais e perinatais na composição corporal e crescimento de recém-nascidos a termo e lactentes:estudo de coorte [The influence of gestational and perinatal factors on body composition and growth of full-term newborns and infants: a cohort study] [master's thesis]. Rio de Janeiro: Fundação Oswaldo Cruz; 2018. Available from: https://www.arca.fiocruz.br/handle/icict/30941

31. Zhu Y, Olsen SF, Mendola P, Yeung EH, Vaag A, Bowers K, et al. Growth and obesity through the first 7 $y$ of life in association with levels of maternal glycemia during pregnancy: a prospective cohort study. Am J Clin Nutr. 2016;103(3):794-800. https://doi.org/10.3945/ajcn.115.121780

32. Hjorth-Hansen A, Salvesen $\emptyset$, Engen Hanem LG, Eggeb $\emptyset$ T, Salvesen K, Vanky E, et al. Fetal Growth and Birth Anthropometrics in Metformin-Exposed Offspring Born to Mothers With PCOS. J Clin Endocrinol Metab. 2018;103(2):740-7. https://doi.org/10.1210/jc.2017-01191

33. Hanem LGE, Stridsklev S, Júlíusson PB, Salvesen $\emptyset$, Roelants M, Carlsen SM, et al. Metformin Use in PCOS Pregnancies Increases the Risk of Offspring Overweight at 4 Years of Age: Follow-Up of Two RCTs. J Clin Endocrinol Metab. 2018;103(4):1612-21. https://doi.org/10.1210/jc.2017-02419

34. Hanem LGE, Salvesen $\varnothing$, Juliusson PB, Carlsen SM, Nossum MCF, Vaage M, et al. Intrauterine metformin exposure and offspring cardiometabolic risk factors (PedMet study): a 5-10 year followup of the PregMet randomised controlled trial. Lancet Child Adolesc Health. 2019;3(3):166-74. https://doi.org/10.1016/S2352-4642(18)30385-7

\section{Figures}

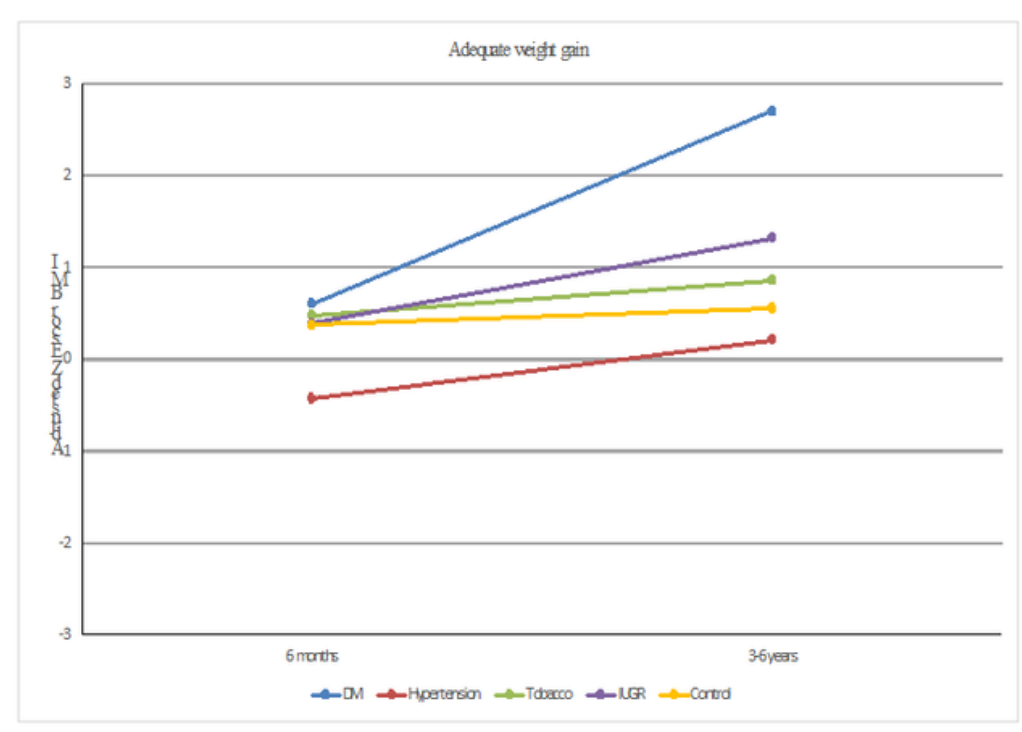

(a)

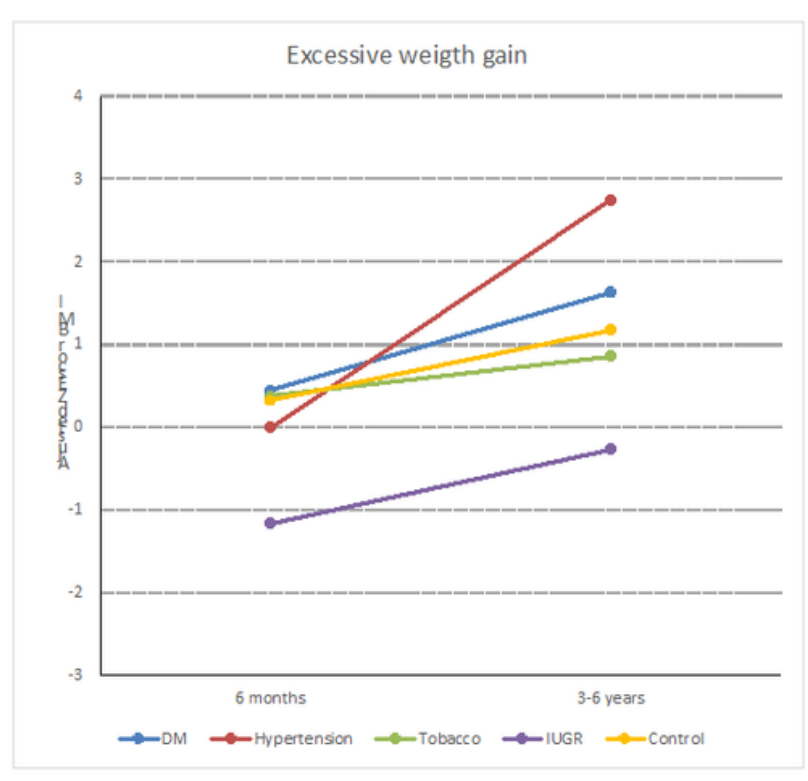

(b)

\section{Figure 1}


a. Variation in Z score - BMI of the child between 6 months of age and preschool age, categorized by adequacy of gestational weight gain adequate to the recommended.

$b$. Variation in Z score - BMI of the child between 6 months of age and preschool age, categorized by adequacy of excessive gestational weight gain. 